\title{
Review: Formulasi Dan Evaluasi Sampo Berbagai Herbal Penyubur Rambut
}

\section{Astiningsih Diah Pravitasari, ${ }^{*}$, Dolih Gozali², Rini Hendriani³, Resmi Mustarichie ${ }^{4}$}

${ }^{1}$ Program Studi Sarjana, Fakultas Farmasi, Universitas Padjadjaran, 2Departemen Farmasetika dan Teknologi Farmasi, Fakultas Farmasi, Universitas Padjadjaran, ${ }^{3}$ Departemen Farmakologi dan Farmasi Klinik, Universitas Padjadajran, ${ }^{4}$ Departemen Analisis Farmasi dan Kimia Medisinal, Fakultas Farmasi, Universitas Padjadjaran. Jl. Raya Bandung Sumedang Km 21 Jatinangor 45363

*E-mail: astiningsih16001@mail.unpad.ac.id

(Submit 4/6/2020, Revisi 23/2/2021, Diterima 26/2/2021, Terbit 25/4/2021)

\begin{abstract}
Abstrak
Sampo adalah produk perawatan rambut paling umum yang digunakan masyarakat dengan bahan utama berupa surfaktan/deterjen. Salah satu tujuan penggunaan sampo adalah untuk mengobati masalah rambut rontok. Pengobatan rambut rontok menggunakan bahan sintetis serperti minoksidil dinilai belum cukup mengatasi rambut rontok karena menimbulkan efek samping yang tidak nyaman. Artikel ini bertujuan untuk membahas formulasi dan evaluasi sampo berbahan herbal perangsang pertumbuhan rambut disertai mekanisme herbal terhadap aktivitas pertumbuhan rambut. Metode yang digunakan adalah kajian pustaka secara elektronik berbagai jurnal internasional dan nasional yang diakses dari situs Google Scholar dan ScienceDirect terhadap jurnal internasional maupun nasional. Hasil kajian pustaka menunjukan perbedaan formula berpengaruh terhadap hasil evaluasi fisik 7 formula sampo herbal. Mekanisme herbal dalam menyuburkan rambut yaitu antioksidan, antiinflamasi, peningkat densitas rambut, pelebar folikel rambut, perpanjang fase anagen, sebagai nutrisi folikel rambut, metabolisme androgen, inhibisi PAK1 (P21-activated kinases) dan induksi reaksi immunologi. Dari artikel ini dapat disimpulkan bahwa formula terbaik sampo adalah formula sampo ekstrak licorice dengan kandungan kombinasi surfaktan dan hasil evaluasi sesuai dengan syarat parameter evaluasi yang telah ditetapkan. Dalam perangsangan pertumbuhan rambut, herbal yang dijadikan sebagai bahan utama sampo memiliki mekanisme yang beragam.
\end{abstract}

Kata kunci: Sampo, herbal, perangsang pertumbuhan rambut, formulasi, evaluasi fisik 


\section{Pendahuluan}

Sampo merupakan salah satu bentuk produk perawatan rambut yang paling umum digunakan untuk membersihkan rambut dan kulit kepala dari kotoran maupun minyak yang menempel, terdiri dari bahan utama berupa surfaktan/deterjen dan bahan tambahan, seperti antioksidan, buffer penstabil $\mathrm{pH}$, agen pendispersi, pengawet, pewarna dan parfum yang berfungsi untuk memenuhi kualitas dan stabilitas sampo ${ }^{1,2}$. Berbagai formulasi sampo dibuat berdasarkan kebiasaan perawatan rambut, kualitas rambut sampai masalah rambut, seperti rambut berminyak, rambut berketombe, dan masalah kebotakan/alopesia. Sampo di pasaran dapat berbentuk cair, krim, serbuk maupun jel $\left.\right|^{3,4}$.

Rambut merupakan bagian dari kulit manusia seperti kuku tetapi tumbuh menjadi bagian terpisah dari kulit yang berfungsi sebagai perlindungan tubuh dari lingkungan. Rambut manusia rata-rata memiliki sekitar 100.000 folikel di dalamnya yang menjalankan fungsi pengaturan pertumbuhan dan diferensiasi epithelial serta siklus pertumbuhan rambut ${ }^{5,6}$. Namun, belakangan kerontokan rambut/alopesia menjadi masalah yang sering terjadi pada sebagian besar masyarakat. Berbagai faktor dapat menjadi penyebab kerontokan rambut, seperti gangguan hormon, usia, kehamilan, konsumsi obat, paparan sinar matahari secara terus-menerus, ataupun gaya hidup. Sediaan rambut untuk mengatasi masalah kerontokan rambut/alopesia dengan kandungan bahan kimia seperti minoksidil dianggap masih belum cukup mengatasi alopesia serta tak jarang menimbulkan efek samping, seperti radang kulit, sakit kepala dan iritasi sehingga pengembangan terhadap obat-obat herbal gencar dilakukan untuk dapat mengatasi kerontokan rambut dengan efek samping yang lebih ringan dibanding sediaan rambut minoksidil, bahkan tanpa efek samping yang berarti ${ }^{7-9}$.

Berbagai penelitian menampilkan berbagai tanaman herbal yang memiliki aktivitas menyuburkan pertumbuhan rambut sampai mengatasi masalah kerontokan rambut, seperti daun katuk, daun pare, daun sirih, daun jambu biji, bawang merah, licorice, bhringhaj serta brahmi. Dengan diketahuinya tanaman-tanaman yang memiliki aktivitas menyuburkan rambut ini, maka penelitian dilanjutkan sampai terbentuk sediaan rambut; sampo. Review artikel ini akan membahas berbagai formulasi dan evaluasi sampo berbahan herbal penyubur rambut yang dirangkum dari berbagai pustaka terkait formulasi sampo dan sampo herbal.

\section{Metode}

Metode yang digunakan dalam penyusunan review artikel ini dimulai dengan melakukan penelusuran pustaka berupa jurnal internasional maupun nasional dengan kata kunci "Sampo herbal penyubur rambut", "Sampo anti kebotakan", "evaluation of anti-hair loss shampoo", "Evaluation of anti-baldness shampoo", "treatment of hair loss-shampo formulation", "formulasi dan evaluasi sampo anti kebotakan", "formulasi dan evaluasi sampo anti alopesia", "hair growth activity herbal shampoo" dan "herbal shampoo for hair growth" dalam Google Scholar dan ScienceDirect. Jurnal-jurnal atau artikel penelitian yang didapat kemudian diseleksi berdasarkan keterkaitan topik melalui judul - 
-dan abstrak, bahasa yang digunakan adalah Bahasa Indonesia dan Inggris serta jurnal atau artikel penelitian berada pada rentang tahun 2010-2020. Sebanyak 46 artikel digunakan sebagai referensi penulisan dengan 8 artikel mengenai sampo dan kerontokan rambut, 7 artikel mengenai formula sampo, 14 artikel mengenai evaluasi sampo, 9 artikel mengenai kandungan senyawa dalam herbal, dan 8 artikel mengenai uji aktivitas tanaman dan mekanisme senyawa.

\section{Hasil dan Pembahasan}

Penggunaan herbal dan ekstrak herbal untuk membersihkan rambut, mengatur rambut serta merawat rambut telah lama dilakukan oleh masyarakat. Belakangan ini, produk perawatan rambut dengan bahan-bahan alami kembali digunakan ${ }^{1,10}$. Ketertarikan terhadap produk-produk herbal didasarkan pada pertimbangan bahwa produk herbal lebih murah serta jarang menyebabkan efek samping yang mengganggu bahkan tidak menimbulkan efek samping saat penggunaannya ${ }^{1}$. Tetapi, pengembangan terhadap formula dan teknik pembuatan terhadap produk berbahan baku herbal atau ekstrak herbal ini masih menjadi salah satu tantangan.

Untuk menyesuaikan dengan kualitas dan keamanan produk sampo di pasaran, maka sampo herbal hasil formulasi perlu dilakukan evaluasi dengan membandingkan parameter yanga tertera dalam tabel $1^{11}$.

Tabel 1. Parameter evaluasi sampo herbal

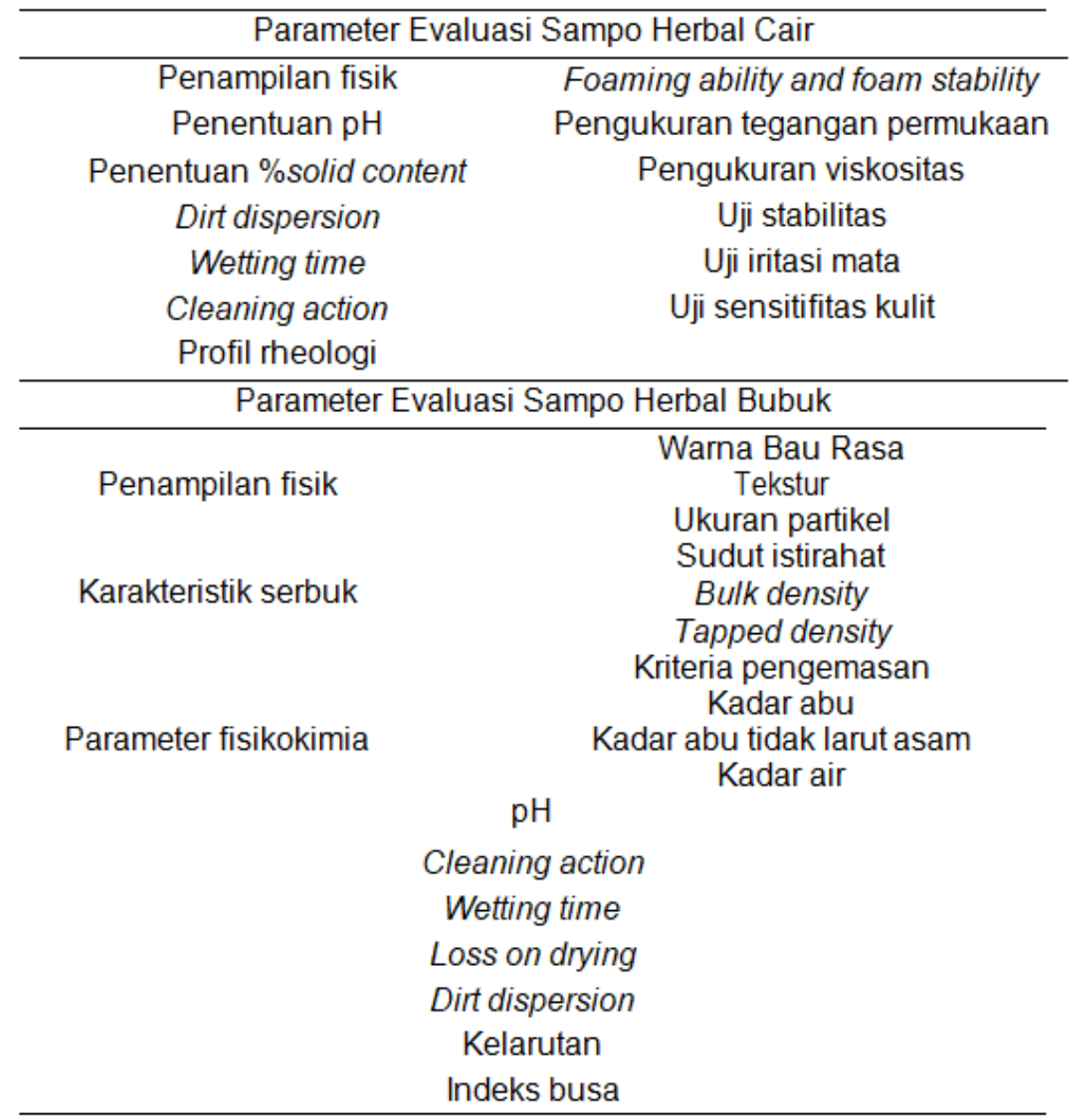


Hasil pencarian artikel riset serta ulasan secara daring kemudian dikerucutkan menjadi 7 artikel penelitian mengenai formulasi dan evaluasi sampo herbal untuk didiskusikan. Artikel riset yang digunakan sebagai referensi penulisan menyajikan data berupa hasil evaluasi dari sampo herbal yang diformulasikan. Pada pengamatan organoleptis sampo dilakukan terhadap bentuk, warna, bau disertai homogenitas sampo. Pada sampo bubuk poliherbal yang diformulasikan oleh Lodha, 2019 yang tertera dalam tabel 4, pengamatan terhadap karakteristik yang mempengaruhi sifat dan kestabilan sampo, seperti sudut istirahat, bulk density, tapped density, sifat alir dan ukuran partikel turut dilakukan ${ }^{12}$.

Hasil pengamatan organoleptis pada mayoritas penelitian menunjukan bahwa sampo hasil formulasi berwarna sama dengan warna ekstrak herbal yang digunakan disertai bau khas ekstrak bila sampo tidak ditambahkan zat pewangi.

Herbal-herbal yang memiliki aktivitas penyubur pertumbuhan rambut kemudian dilakukan penelitian lanjutan, yaitu mengenai proses formulasi herbal menjadi sampo herbal dan evaluasi terhadap sediaan sampo herbal yang terbentuk. Bentuk sampo herbal berupa sampo herbal serbuk dan sampo herbal cair. Formula sampo-sampo herbal ini disajikan dalam tabel 2-tabel 15.

Formula 1: Preparation and Evaluation of Herbal Hair Growth Promoting Shampoo Formulation Containing Piper Betle and Psidium guajava leaves extract

Tabel 2. Formula sampo kombinasi daun jambu biji dan daun sirih

\begin{tabular}{lccc}
\hline \multicolumn{1}{c}{ Bahan } & $\mathbf{F C}_{\mathbf{1}}$ & $\mathbf{F C}_{\mathbf{2}}$ & $\mathbf{F C}_{3}$ \\
\hline Ekstrak daun jambu biji (g) & 3 & 2 & 1 \\
Ekstrak daun sirih (g) & 1 & 2 & 3 \\
Sodium Lauril Sulfat $(\mathrm{g})$ & 8 & 8 & 8 \\
Trietanolamin $(\mathrm{mL})$ & 3,5 & 3,5 & 3,5 \\
Asam Oleat $(\mathrm{mL})$ & 4 & 4 & 4 \\
Metilparaben $(\mathrm{g})$ & 0,25 & 0,25 & 0,25 \\
Minyak lavender (tetes) & 2 & 2 & 2 \\
EDTA & 0,15 & 0,15 & 0,15 \\
Air & qs & qs & qs \\
\hline
\end{tabular}

Tabel 3. Evaluasi sampo kombinasi daun jambu biji dan daun sirih

\begin{tabular}{ccc}
\hline No & Evaluasi & Hasil \\
\hline 1. & Organoleptis & Warna cokelat gelap, bau khas, tekstur halus, \\
berbentuk cairan dan tanpa butiran halus. \\
2. & & $4,7-5,3$ \\
3. & Fo & Nilai baik \\
4. & Aktivitas pertumbuhan & Hasil yang baik dalam mengurangi rambut rontok \\
& rambut & dan meningkatkan pertumbuhan rambut. \\
\hline
\end{tabular}


Pada formula 1 yang terdapat dalam tabel 2, sampo herbal dengan kombinasi ekstrak daun sirih (Piper betle) dan daun jambu (Psidium guajava) dibagi menjadi tiga formula yang dibedakan berdasarkan kombinasi konsentrasi ekstrak yang digunakan. Ekstrak daun sirih dan daun jambu diekstraksi dengan mendidihkan 30 gram daun pada suhu $50^{\circ} \mathrm{C}$ dalam $900 \mathrm{~mL}$ pelarut air secara terpisah lalu dikeringkan sampai terbentuk pasta $^{13}$. Ekstrak daun sirih mengandung steroid-triterpenoid, alkaloid, kuinon, flavonoid yang mencegah terjadinya kerusakan dan kerontokan rambut akibat inflamasi dan radikal bebas melalui mekanisme antioksidan dan antiinflamasi ${ }^{13,14}$. Sedangkan, ekstrak daun jambu biji menyuburkan pertumbuhan rambut dengan meningkatkan densitas rambut ${ }^{15,16}$.

Formulasi sampo herbal ini menggunakan kombinasi sodium lauril sulfat (SLS) sebagai surfaktan utama dan trietanolamin (TEA) sebagai surfaktan sekunder. Sodium lauril sulfat (SLS) termasuk ke dalam surfaktan golongan anionik dan merupakan surfaktan yang paling umum digunakan dalam formulasi sampo. Surfaktan golongan anionik memiliki kemampuan membersihkan kotoran serta sebum yang sangat baik dan membentuk busa yang lebih stabil dibandingkan dengan surfaktan golongan lain²,17.

Walaupun surfaktan golongan anionik memiliki kemampuan membentuk busa dan kemampuan membersihkan yang baik, tetapi surfaktan golongan anionik berpotensi meningkatkan muatan negatif pada rambut. Peningkatan muatan negatif pada rambut akan menyebabkan peningkatan gesekan antar rambut sehingga rambut menjadi kusut bahkan rusak ${ }^{18}$. Untuk meminimalisir kerusakan yang dapat ditimbulkan oleh penggunaan surfaktan anionik, surfaktan golongan amfoterik atau nonionik ditambahkan sebagai surfaktan sekunder. Selain meminimalisir kerusakan rambut, penambahan surfaktan sekunder pun memberikan keuntungan, yaitu melembutkan rambut $^{2,18}$.

Ketiga formula sampo ini kemudian dilanjutkan ke tahap evaluasi terhadap parameter fisik, $\mathrm{pH}$, foamability dan aktivitas pertumbuhan rambut. Hasil evaluasi menunjukan kesesuaian dengan standar yang telah ditetapkan, tetapi $\mathrm{pH}$ ketiga formula sampo herbal menunjukan kecenderungan mendekati asam. Kecenderungan $\mathrm{pH}$ mendekati asam berasal dari kandungan kimia daun jambu biji berupa asam psidiolat, asam ursolat, asam kategonat, asam oleanolat, asam guajavolat, asam krategolat, guajaverin, isokuersetin, hiperin, senyawa flavonol, tannin, akusarinin dan kuersetin ${ }^{13,19}$. 
Formula 2: Formulation and Evaluation of Licorice Shampoo in Comparison with Commercial Shampoo

Tabel 4. Formula sampo licorice

\begin{tabular}{lcc}
\hline \multicolumn{1}{c}{ Bahan } & Bentuk Fisik & $\%$ \\
\hline $\begin{array}{l}\text { Sodium lauril eter sulfat } \\
\text { (SLES) (Texapon }{ }^{\circledR} \text { N70) }\end{array}$ & Semisolid & 20 \\
Cocamide dietanolamin & Likuid & 2,5 \\
(CDE/COMPERLAN ${ }^{\circledR}$ KD) & Likuid & 10 \\
Dehyton® & Solid, Serbuk & 2 \\
Natrium Klorida & Solid, Serbuk & 0,2 \\
Metil dan propil paraben & Likuid & qs \\
Trietanolamin & Solid, Serbuk & 0,15 \\
Propil paraben (Benazole & \\
Ekstrak kering licorice & Solid, Serbuk & 10 \\
Minyak Citrus aurantium & Likuid, minyak & qs \\
Air & Likuid & Ad 100 \\
\hline
\end{tabular}

Tabel 5. Evaluasi sampo licorice

\begin{tabular}{ccc}
\hline No & Evaluasi & Hasil \\
\hline 1. & Organoleptis & Warna cokelat gelap \\
2. & $\mathrm{pH}$ & 8,7 \\
3. & $\%$ solid content & $81 \%$ \\
4. & Cleansing ability & $90 \%$ \\
5. & Foamability & $150 \mathrm{~mL}$ \\
6. & Wetting time & 18 detik \\
7. & Viskositas & $15 \mathrm{cp}$ \\
\hline
\end{tabular}

Pada formula 2 yang tertera dalam tabel 4, sampo herbal licorice menggunakan kombinasi dari 3 jenis surfaktan, yaitu surfaktan utama sodium lauril eter sulfat (SLES), surfaktan nonionik cocamide dietanolamin dan surfaktan amfoterik Dehyton ${ }^{\circledR}$. Kombinasi ketiga surfaktan ini berpengaruh pada cleansing abilitykemampuan pembersihan dan foamability sampo herbal bila dibandingkan dengan produk sampo di pasaran. Sampo herbal licorice memiliki nilai kemampuan pembersihan yang lebih tinggi, yaitu $90 \%$ sedangkan sampo pasaran hanya berada pada nilai $58 \%$. Perbedaan yang signifikan ini berasal dari konsentrasi surfaktan utama, sodium lauril eter sulfat (SLES), dalam formula sampo herbal licorice lebih tinggi dibandingkan konsentrasi surfaktan yang disarankan untuk sampo obat sebesar $<10 \%$ dan bahan herbal dengan kandungan saponin tinggi juga menjadi faktor pengaruh ${ }^{20}$. 
Sampo herbal licorice juga memiliki nilai foamability lebih tinggi, yaitu $150 \mathrm{~mL}$ sedangkan sampo pasaran hanya berada pada nilai $120 \mathrm{~mL}$. Hal ini karena sampo herbal mengkombinasikan surfaktan anionik (SLES) dengan surfaktan nonionik (Cocamide dietanolamin) sebagai agen penambah dan penstabil busa dan surfaktan amfoterik (Dehyton $\left.{ }^{\circledR}\right)^{20}$.

Nilai $\mathrm{pH}$ sampo ekstrak licorice yang tertera dalam tabel 5 menunjukan nilai yang cenderung basa. Penggunaan surfaktan utama berupa natrium lauril eter sulfat dengan konsentrasi $20 \%$ menjadi salah satu faktor nilai $\mathrm{pH}$ sampo yang cenderung basa. Natrium lauril eter sulfat merupakan surfaktan yang paling umum digunakan dalam pembuatan sampo, termasuk ke dalam surfaktan golongan anionik dengan kutub hidrofilik bermuatan negatif (ion sulfat bermuatan negatif) 2,20 .

Pada pengujian \%solid content, nilai yang didapat melebihi syarat \%solid content yang dianjurkan. Pengujian \%solid sampo bertujuan untuk menentukan banyaknya padatan dalam sampo. Nilai \%solid sampo yang baik berada pada rentang $20-30 \%$ agar sampo mudah diaplikasikan dan dicuci dari rambut. Nilai \%solid yang terlalu besar akan membuat sampo sulit untuk diaplikasikan dan dicuci dari rambut. Sedangkan nilai yang terlalu kecil akan membuat sampo terlalu cair dan mudah hilang dari rambut saat pengaplikasian ${ }^{1,21,22}$.

Ekstrak licorice mengandung senyawa isoflavon (kumarin, glabridin), glycyrrhizin, liquiritin dan liquiritigenin yang merangsang pertumbuhan rambut melalui metabolism androgen (mekanisme estrogen-dependent) yang berpengaruh pada penebalan rambut anagen dan perpanjangan fase anagen ${ }^{20,23}$.

Formula 3: Preparation of Herbal Shampo (HS) by Green Method and their Characterization

Tabel 6. Formula sampo kombinasi ekstrak herbal

\begin{tabular}{lc}
\hline \multicolumn{1}{c}{ Bahan } & $\%$ \\
\hline Ekstrak Herbal & 10 \\
SLES & 30 \\
Gliserin & 18 \\
Aloevera & 12 \\
Cocamideopropylbetane (CAPB) & 6 \\
Metil paraben & 0,5 \\
Sodium Benzoat & 1,5 \\
Etilen Glikol Monostearat (EGMS) & 4 \\
Cocamono & 4 \\
Air & qs \\
\hline
\end{tabular}


Tabel 7. Evaluasi sampo kombinasi ekstrak herbal

\begin{tabular}{ccc}
\hline No. & Evaluasi & Hasil \\
\hline 1. & Organoleptis & $\begin{array}{c}\text { Bentuk sampo kental, warna semi putih } \\
\text { transparan }\end{array}$ \\
2. & $\mathrm{pH}$ & 6,5 \\
3. & \%solid content & $0,1 \mathrm{~g} / \mathrm{L}$ \\
4. & Cleansing action & $15 \%$ \\
5. & Foamability & Baik \\
6. & Wetting time & 3 detik \\
7. & Dirt Dispersion & Ringan \\
\hline
\end{tabular}

Pada formula 3 yang tertera dalam tabel 6 , surfaktan utama yang digunakan dalam formula adalah SLES konsentrasi $30 \%$, dikombinasikan dengan cocamono sebagai agen pengental dan CAPB sebagai penstabil busa. Hasil evaluasi dari formula sampo herbal menunjukan kesesuaian hasil untuk parameter $\mathrm{pH}$, \%solid content, foamability, wetting time dan dirt dispersion. Parameter cleansing action/kemampuan pembersihan menunjukan nilai yang tidak memenuhi syarat kemampuan pembersihan sampo yang baik pada rentang 18-30\%. Pengujian terhadap kemampuan pembersihan sampo/cleansing ability dilakukan untuk mengetahui banyaknya lemak pada wol yang dapat dibersihkan oleh sampo. Lemak pada wol ini menggambarkan lemak yang terdapat pada kulit kepala konsumen. Kemampuan membersihkan sampo akan meningkat sejalan dengan peningkatan nilai konsentrasi surfaktan/deterjen yang digunakan juga pengaruh teknik pembuatan ${ }^{24,25}$.

Pengujian terhadap parameter foamability menunjukkan nilai yang baik. Pengujian foamability biasanya akan didampingi dengan pengujian foam stability. Kedua pengujian ini bertujuan untuk mengetahui kemampuan sampo membentuk busa serta kestabilan busa selama pemakaian. Walaupun pembentukan busa tidak berhubungan langsung dengan kemampuan pembersihan sampo tetapi pembentukan busa menjadi salah satu parameter penting bagi konsumen karena konsumen cenderung memilih sampo yang cepat membentuk banyak busa ${ }^{17,26}$.

Sampo berbahan herbal dengan kandungan saponin akan menghasilkan busa yang lebih banyak. Saponin memiliki karakteristik seperti deterjen atau surfaktan dan merupakan agen pembusa yang baik serta menghasilkan busa yang stabil ${ }^{27}$. Aktivitas deterjen yang dimiliki senyawa saponin ditunjukan melalui penelitian yang dilakukan oleh Mesgarzadeh, et al., 2017 terhadap saponin yang diisolasi dari Panax ginseng menggunakan tensinometer du Nuoy. Penelitian ini membuktikan bahwa senyawa saponin dapat menurunkan tegangan permukaan sampai titik di bawah Plateu region ${ }^{28}$. 
Formula 4: Formulation and Evaluation of Polyherbal Shampoo to Promote Hair Growth and Provide Antidandruff Action

Tabel 8. Formula sampo poliherbal

\begin{tabular}{lc}
\hline \multicolumn{1}{c}{ Bahan } & Jumlah $(\mathbf{g})$ \\
\hline Serbuk Bhringraj & 2,50 \\
Henna & 1,25 \\
Lemon & 2,50 \\
Amla & 2,50 \\
Neem & 1,25 \\
Aloevera & 2,50 \\
Serbuk Methi & 2,50 \\
Serbuk Ashwagandha & 2,50 \\
Reetha & 2,50 \\
Akar Brahmi & 2,50 \\
Daun Paan & 2,50 \\
Nagarmotha & 2,50 \\
Tulsi & 2,50 \\
Hibiscus Rosasinesis & 2,50 \\
Shikakai & 0,25 \\
Daun The Hijau & 2,50 \\
Triphala & 2,50 \\
Sodium Lauril Sulfat & 1 \\
Air & qs \\
\hline
\end{tabular}

Tabel 9. Evaluasi sampo poliherbal

\begin{tabular}{ccc}
\hline No & Evaluasi & Hasil \\
1. & Organoleptis & $\begin{array}{c}\text { Warna cokelat gelap, berbentuk serbuk, } \\
\text { bau enak dan tekstur lembut }\end{array}$ \\
2. & $\mathrm{pH}$ & 5,47 \\
& & $\begin{array}{c}\text { Ukuran partikel } 25-20 \mu \mathrm{m} \\
\text { Sudut istirahat } 31{ }^{\circ} \mathrm{C}\end{array}$ \\
bulk density $0,4577 \mathrm{~g} / \mathrm{cm}^{3}$ \\
3. & Karakteristik serbuk & Kadar abu $4,01 \%$ \\
& & Kadar abu tidak larut asam $1,61 \%$ \\
4. & Parameter fisikokimia & 142,85 \\
5. & Foaming index & $171 \pm 5$ detik \\
6. & Wetting time & Larut dalam air \\
7. & Kelarutan & Moderat \\
8. & Dirt dispersion & \\
\hline
\end{tabular}


Pada formula 4 yang tertera dalam tabel 8, sampo yang diformulasikan berbentuk serbuk dengan bahan utama yang berfungsi sebagai surfaktan adalah Reetha/Sapindus mukorossi dan Shikakai/Acacia concinna. Reetha dan shikakai secara tradisional digunakan oleh masyarakat India untuk membersihkan rambut. Kedua tumbuhan menghasilkan hasil yang positif dalam pembentukan busa saat dikombinasikan dengan Na-lauril sulfat ditunjukkan dari nilai foaming index sebesar $142,85^{12}$.

Evaluasi yang dilakukan terhadap formula sampo serbuk poliherbal mencakup parameter karakteristik serbuk berupa ukuran partikel, sudut istirahat, bulk density, tapped density, parameter fisikokimia berupa kadar abu dan kadar abu tidak larut asam, wetting time/waktu pembasahan serta dirt dispersion. Waktu pembasahan/wetting time bergantung pada konsentrasi surfaktan/deterjen yang digunakan dalam formulasi sampo. Pengujian ini bertujuan untuk mengetahui efektifitas surfaktan yang digunakan. Nilai wetting time yang besar menunjukan bahwa sampo mengandung deterjen dalam jumlah yang sedikit ${ }^{21,29}$. Dirt dispersion dilakukan untuk menggambarkan kekuatan pembersihan sampo ${ }^{21}$. Pada pengujannya, bila sampo menyebabkan tinta terkonsentrasi pada busa yang terbentuk maka sampo dianggap memiliki kualitas/daya pembersihan yang buruk. Tinta yang dianggap sebagai kotoran harus tetap berada di bagian air. Kotoran yang tertahan pada busa akan sulit untuk dibilas dan akan menempel kembali di rambut ${ }^{26}$.

Serbuk bhringraj (Eclipta alba (L.) Hassk) yang digunakan dalam formula sampo herbal mengandung senyawa seperti daucosterol, ecliptasaponin C, stigmasterol-3-Oglukosida, $\beta$-sitosterol yang berpengaruh pada perpanjangan usia folikel anagenik akhir dan pencegahan miniaturisasi folikel sehingga terjadi pelebaran folikel dan perpanjangan fase anagen ${ }^{30,31}$. Serbuk brahmi (Bacopa monniere) mengandung senyawa seperti alkaloid, sitosterol, stigmasterol, bakosida, saponin, triterpenoid dan merangsang pertumbuhan rambut dengan mekanisme yang sama seperti bhringraj $30,32,33$. Aloevera yang terkandung dalam sampo herbal pun berperan dalam merangsang pertumbuhan rambut. Peran ini berkaitan dengan kandungan senyawa dalam Aloevera yang berfungsi sebagai nutrisi untuk folikel rambut ${ }^{30,34}$.

Formula 5: Formulasi dan Uji Stabilitas Fisik Sampo Ekstrak Etanol Daun Pare

Tabel 10. Formula sampo ekstrak daun pare

\begin{tabular}{lcccc}
\hline \multicolumn{1}{c}{ Bahan } & $\mathbf{F}_{\mathbf{1}}(\%)$ & $\mathbf{F}_{\mathbf{2}}(\%)$ & $\mathbf{F}_{\mathbf{3}}(\%)$ & $\mathbf{F}_{\mathbf{4}}(\%)$ \\
\hline Ekstrak daun pare & 1 & 2 & 3 & 4 \\
HEC & 0,90 & 0,90 & 0,90 & 0,90 \\
Sodium Lauril Sulfat & 9 & 9 & 9 & 9 \\
Trietanolamin & 1 & 1 & 1 & 1 \\
Propilen Glikol & 15 & 15 & 15 & 15 \\
Nipagin & 0,18 & 0,18 & 0,18 & 0,18 \\
Nipasol & 0,02 & 0,02 & 0,02 & 0,02
\end{tabular}




\begin{tabular}{lcccc}
$\mathrm{Na}_{2}$ EDTA & 0,10 & 0,10 & 0,10 & 0,10 \\
Green tea oil & 0,50 & 0,50 & 0,50 & 0,50 \\
Akuades & qs & qs & qs & qs \\
\hline
\end{tabular}

Tabel 11. Evaluasi sampo ekstrak daun pare

\begin{tabular}{lcc}
\hline No & Evaluasi & Hasil \\
\hline 1. & Organoleptis & $\begin{array}{c}\text { Bentuk cair, berwarna kuning tua-coklat, } \\
\text { ekstrak terdispersi sempurna }\end{array}$ \\
2. & $\mathrm{pH}$ & $6-6,30$ \\
3. & Bobot jenis & $1,0263-1,0330 \mathrm{gram} / \mathrm{ml}$ \\
4. & Viskositas & $2000-4000 \mathrm{CPs}$ \\
5. & Uji stabilitas & Sampo stabil pada penyimpanan di suhu \\
& & $4^{\circ}$ dan $40^{\circ} \mathrm{C}$ \\
\hline
\end{tabular}

Pada formula 5 yang tertera dalam tabel 10, Hidroksi etil selulosa (HEC) ditambahkan sebagai pengental dengan konsentrasi $0,9 \%$ pada seluruh formula. Sampo herbal ekstrak daun pare dibuat menjadi 4 formula dengan variasi konsentrasi ekstrak $1 \%, 2 \%$, $3 \%$ dan $4 \%$. Keempat formulasi dilanjutkan ke tahap evaluasi dengan melakukan pengujian terhadap parameter tampilan fisik, $\mathrm{pH}$, bobot serta viskositas. Hasil yang didapat sesuai dengan standar mengacu pada standar yang telah ditetapkan SNI 062692-1992 ${ }^{35}$.

Bobot jenis ditetapkan untuk memprediksi kemudahan sediaan sampo mengalir dari kemasan atau kemudahan penuangan produk. Syarat bobot jenis berdasarkan SNI 062692-1992 adalah minimal 1,020 gram/ml. Parameter lain yang dapat digunakan untuk memprediksi penuangan produk adalah viskositas. Viskositas menjadi salah satu faktor yang berpengaruh terhadap penampilan sampo, stabilitas sampo, masa penyimpanan sampo selain kemudahan penuangan dari kemasan. Beberapa penelitian menunjukan bahwa viskositas akan meningkat seiring dengan meningkatnya nilai konsentrasi ekstrak yang ditambahkan ${ }^{36}$. Namun, penelitian yang dilakukan Jusnita \& Syah, 2017 menunjukkan bahwa kenaikan nilai konsentrasi ekstrak daun pare menyebabkan penurunan nilai viskositas sampo. Hal ini dapat terjadi akibat kandungan kadar air yang tinggi dalam ekstrak pare, yaitu sebesar $9,04 \%{ }^{35}$.

Formula 6: Evaluasi Sifat Fisik Sediaan Sampo Ekstrak Daun Katuk dengan Berbagai Variasi Agen Viskositas

Tabel 12. Formula sampo ekstrak daun katuk

\begin{tabular}{lccc}
\hline \multicolumn{1}{c}{ Bahan } & $\mathbf{F}_{\mathbf{1}}(\%)$ & $\mathbf{F}_{\mathbf{2}}(\%)$ & $\mathbf{F}_{\mathbf{3}}(\%)$ \\
\hline Ekstrak daun katuk & 0,05 & 0,05 & 0,05 \\
Sodium Lauril Sulfat & 2,5 & 2,5 & 2,5 \\
HPMC & 0,5 & 0,75 & 1
\end{tabular}


Cocamide DEA

Vitamin C

4

Na-Benzoat

0,02

4

Dimeticone

0,15

0,02

0,02

Asam Sitrat

0,05

0,15

0,15

Menthol

qs

0,05

0,05

D\&C Green

0,5

qs

qs

Etanol

qs

0,5

0,5

Akuades

qs

qs

qs

Ad 100

qs

qs

Tabel 13. Evaluasi sampo ekstrak daun katuk

\begin{tabular}{lcc}
\hline No & Evaluasi & Hasil \\
\hline 1. & Organoleptis & Berbau melati dengan wana hijau muda \\
& & $\mathrm{F} 16,43$ \\
2. & $\mathrm{pH}$ & $\mathrm{F} 26,31$ \\
& & $\mathrm{~F} 36,45$ \\
3. & Bobot jenis & $1,0263-1,0330 \mathrm{gram} / \mathrm{ml}$ \\
& & $\mathrm{F} 1466,66 \mathrm{dPaS}$ \\
4. & Viskositas & $\mathrm{F} 2600 \mathrm{dPaS}$ \\
& & $\mathrm{F} 3700 \mathrm{dPaS}$ \\
& & $\mathrm{F} 12,9 \mathrm{~cm}$ \\
5. & Uji tinggi busa & $\mathrm{F} 23,16 \mathrm{~cm}$ \\
& & $\mathrm{~F} 33,26 \mathrm{~cm}$ \\
\hline
\end{tabular}

Pada formula 6 yang tertera dalam tabel 12, sampo ekstrak daun katuk menggunakan sodium lauril sulfat (SLS) sebagai surfaktan utama yang dikombinasikan dengan cocamide DEA dan HPMC (Hydroxypropyl Methylcelluloce). HPMC yang ditambahkan sebagai bahan pengental dalam ketiga formula sampo memiliki variasi konsentrasi $0,5 \%, 0,75 \%$ dan $1 \%$ untuk melihat pengaruhnya terhadap viskositas sampo. Peningkatan konsentrasi HPMC terbukti memberikan pengaruh yang signifikan terhadap kenaikan viskositas sampo ${ }^{37}$. Pengaruh penambahan HPMC terhadap peningkatan viskositas sampo dapat pula ditunjukkan melalui hasil formulasi sampo daun katuk oleh Rashati \& Eryani, 2019 yang membandingkan pengaruh bahan pengental; Na-CMC, HPMC dan karbopol terhadap viskositas sampo. Penelitian ini menunjukan bahwa formula sampo ekstrak daun katuk dengan HPMC 1,5\% sebagai bahan pengental memiliki viskositas tertinggi diantara formula sampo dengan $\mathrm{Na}-\mathrm{CMC}$ dan karbopol sebagai bahan pengental ${ }^{39}$.

Sampo dengan formula HPMC sebagai bahan pengental cenderung akan menghasilkan busa yang lebih stabil. HPMC memiliki peran dalam menjaga kestabilan busa melalui karakteristik "interfacial gelation". HPMC membentuk lapisan kental di sekitar gelembung busa yang terbentuk. Lapisan kental ini memperkuat dinding busa, menahan laju drainase air serta menjadikan busa lebih padat dan stabil ${ }^{40}$. 
Formula 7: Formulation and Evaluation of Onion Hair Nourishing Shampoo

Tabel 14. Formula sampo ekstrak bawang merah

\begin{tabular}{lccc}
\hline \multicolumn{1}{c}{ Bahan } & $\mathbf{F}_{\mathbf{1}}$ & $\mathbf{F}_{\mathbf{2}}$ & $\mathbf{F}_{\mathbf{3}}$ \\
\hline Minyak kelapa $(\mathrm{mL})$ & 3,60 & 3,60 & 3,60 \\
Minyak jarak $(\mathrm{mL})$ & 0,80 & 0,80 & 0,80 \\
Kalium hidroksida $(\mathrm{g})$ & 1,06 & 1,06 & 1,06 \\
Gliserol $(\mathrm{mL})$ & 0,80 & 0,80 & 0,80 \\
Boraks $(\mathrm{g})$ & 0,04 & 0,04 & 0,04 \\
Akasia $(\mathrm{g})$ & 0,04 & 0,04 & 0,04 \\
Ekstrak Allium cepa $(\mathrm{mL})$ & 1 & 2 & 3 \\
Minyak kayu putih $(\mathrm{mL})$ & 1 & 1 & 1 \\
Natrium bikarbonat $(\mathrm{g})$ & 0,12 & 0,12 & 0,12 \\
Lemon (mL) & 1 & 1 & 1 \\
Metil paraben $(\mathrm{g})$ & 0,06 & 0,06 & 0,06 \\
Akuades & $\mathrm{Ad} 20$ & $\mathrm{Ad} 20$ & $\mathrm{Ad} \mathrm{20}$ \\
\hline
\end{tabular}

Tabel 15. Evaluasi sampo ekstrak bawang merah

\begin{tabular}{|c|c|c|}
\hline No & Evaluasi & Hasil \\
\hline 1. & Organoleptis & $\begin{array}{c}\text { Cairan jernih berwarna kuning } \\
\text { kecoklatan tanpa bau khas } \\
\text { F1 } 14\end{array}$ \\
\hline 2. & $\mathrm{pH}$ & $\begin{array}{l}\text { F2 } 13 \\
\text { F3 } 10\end{array}$ \\
\hline 3. & Foaming ability & $\begin{array}{c}\text { baik } \\
\mathrm{F} 125,73 \text { dyne/cm }\end{array}$ \\
\hline 4. & Tegangan permukaan & $\begin{array}{c}\text { F2 19,60 dyne/cm } \\
\text { F3 29,20 dyne/cm } \\
\text { F1 4,13 cp }\end{array}$ \\
\hline 5. & Viskositas & $\begin{array}{l}\text { F2 } 10,88 \mathrm{cp} \\
\text { F3 } 11,89 \mathrm{cp}\end{array}$ \\
\hline 6. & Uji iritasi kulit & Tidak iritan \\
\hline
\end{tabular}

Pada formula 7 yang tertera dalam tabel 14, formula sampo ekstrak bawang merah yang diformulasi Rafik, et al., 2018 tidak menggunakan kombinasi dua surfaktan di dalamnya. Sampo ekstrak bawang merah ini menggunakan gliserol sebagai surfaktan dengan tambahan minyak kelapa dan minyak jarak tersaponifikasi dengan kalium hidroksida $(\mathrm{KOH})$. Reaksi saponifikasi merupakan reaksi hidrolisis trigliserida lemak atau minyak oleh senyawa basa membentuk sabun dan gliserol ${ }^{41}$. 
Pada hasil evaluasi terhadap parameter tampilan fisik, $\mathrm{pH}$, foaming ability, tegangan permukaan, viskositas, dan uji iritasi kulit, nilai $\mathrm{pH}$ sampo herbal berada pada rentang $\mathrm{pH}$ basa kuat. Pengukuran $\mathrm{pH}$ sampo herbal hasil formulasi harus memenuhi syarat yang telah ditetapkan SNI 06-2692-1992, yaitu berada pada rentang 5,0-9,0. Pengukuran $\mathrm{pH}$ dilakukan untuk memastikan keamanan sampo agar sampo tidak mengiritasi kulit kepala dan mata. $\mathrm{pH}$ sampo memegang peranan penting menjaga keseimbangan $\mathrm{pH}$ kulit kepala ${ }^{20,42}$.

Nilai $\mathrm{pH}$ sampo dengan perbedaan yang cukup jauh dengan $\mathrm{pH}$ kulit kepala memiliki kecenderungan mengiritasi dan membuat kulit kepala kering ${ }^{43}$. Sebagian besar sampo di pasaran cenderung bersifat netral atau sedikit asam. Sampo dengan nilai $\mathrm{pH}$ sedikit asam menyebabkan lapisan terluar rambut/kutikula menyusut lalu menempel pada batang rambut sedangkan nilai $\mathrm{pH}$ sampo lebih dari 8,5 dapat merusak ikatan disulfide rambut, nilai $\mathrm{pH}$ lebih dari 12 akan merusak ikatan hidrogen dan jembatan garam. Bila ikatan disulfida, ikatan hidrogen dan jembatan garam hilang, maka rambut menjadi kasar, kusut dan rusak ${ }^{44,45}$.

Bawang merah (Allium cepa L.) yang digunakan dalam formulasi sampo herbal mengandung senyawa allin, steroid, fruktosa, saponin, flavonoid dan vitamin $C^{15,30}$. Bawang merah menginduksi reaksi immunologi (dengan kemungkinan dermatitis ringan) yang berefek pada induksi pertumbuhan rambut ${ }^{30,46}$.

\section{Simpulan}

Berdasarkan hasil kajian pustaka, formula terbaik sampo herbal adalah formula sampo licorice yang terdiri dari ekstrak licorice 10\%, kombinasi surfaktan berupa sodium lauril eter sulfat (SLES) 20\%, cocamidietanolamin (CDEA) 2,5\% dan Dehyton 10\%, serta tambahan $\mathrm{NaCl} 2 \%$ sebagai agen pengental, TEA sebagai pengatur $\mathrm{pH}$, metil-propil paraben $0,2 \%$ sebagai pengawet dan akuades dengan hasil evaluasi sesuai dengan syarat parameter evaluasi yang ditetapkan. Mekanisme herbal dalam aktivitas perangsang pertumbuhan rambut melalui mekanisme beragam, yaitu sebagai antioksidan, antiinflamasi, peningkat densitas rambut, pelebar folikel rambut, perpanjang fase anagen, sebagai nutrisi folikel rambut, terlibat dalam metabolisme androgen, inhibisi PAK1 dan induksi reaksi immunologi.

\section{Ucapan Terima Kasih}

Penulis mengucapkan terimakasih kepada Bapak Dr. Apt. Dolih Gozali, M.S., Ibu Dr. apt. Rini Hendriani, M.Si., dan Prof. apt. Resmi Mustarichie, Ph.D., M.Sc. selaku dosen pembimbing yang telah membantu dalam pemilihan tema serta bersedia membimbing dan memberikan kritik dan saran serta perbaikan dalam proses penulisan artikel review ini. 


\section{Daftar Pustaka}

1. K. A B, S. A K. Formulation, Evaluation and Comparison of the Herbal Shampoo with the Comercial Shampoos. J Basic Appl Sci. 2014;XXX:1-5.

2. Trüeb RM. Shampoos: Ingredients, Efficacy and Adverse Effects. JDDG. 2007;5:356-65.

3. Preethi JP, Padmini K, Srikath J, Lohita M, Swetha K, Vengal Rao P. A Review on Herbal Shampoo and Its Evaluation. Asian J Pharm Ana. 2018;3(4):153-6.

4. Sharma RM, Shah K, Patel J. Evaluation of Prepared Herbal Shampoo Formulations and to Compare Formulated Shampoo with Marketed Shampoo. Int J Pharm Pharm Sci. 2011;3(4):402-5.

5. Buhl AE. Minoxidil's Action in Hair Follicles. J Invest Dermatol. 1991;73-4.

6. Rassman W, Pak J, Schweiger E, Bernstein R. Hair Loss and Replacement for Dummies. 2009.

7. Messenger AG, Rundergren J. Minoxidil: MEchanism of Action on Hair Growth. $\mathrm{Br}$ J Dermatol. 2004;

8. Seikh S, Ahmad A, Ai SM, Ahmad MU, Paithankar M, Saptarshi D, et al. A New Topical Formulation of Minoxidil and Finasteride Improves Hair Growth in Men with Androgenetic Alopecia. J Clin ExpDermatol Res. 2015;6(1).

9. Tyagi A. A Review on Hair Loss and Damage. Res Rev J Med. 2016;3(2).

10. Vijetha JR, Grace XF, Shanmuganathan S, Chamundeeswari D. Preparation and Evaluation of Polyherbal Shampoo Powder. Int J Pharm Biol Sci. 2013;3(60-66).

11. Gubitosa J, Rizzi V, Fini P, Cosma P. Hair Care Cosmetics: From Traditional Shampoo tp Solid Clay and Herbal Shampoo. Cosmetics. 2019;6(13):1-16.

12. Lodha G. Formulation and Evaluation of Polyherbal Shampoo to Promote Hair Growth and Provide Antidandruff Action. J Drug Deliv Ther. 2019;9(4-A):296-300.

13. Joshi N, Patidar K, Solanki R, Mahawar V. Preparation and Evaluation of Herbal Hair Growth Promoting Shampoo Formulation Containing Piper betle and Psidium guajava Leaves Extract. Int J Green Pharm. 2018;12(4):835-9.

14. Elfahmi, Wirasutisna KR, Desyane HK. Senyawa Aktif Lignan dari Buah Lada Hitam (Piper ningrum L.) dan Daun Sirih (piper betle L.). Acta Pharm Indones. 2012;XXXVII(1):14-7.

15. Semwal BC, Agrawal KK, S. T, Sharma S. Alopecia: Switch to Herbal Medicine. J Pharm Res Opin. 2011;1(4):101-4.

16. Gavatin NP, Tailang M, Gupta BK, Subhey EA, Lokhande AK, Vyax N. Therapeutic Potential of Psidium guajava and Its polyherbal Formulation on Chemotherapy Induced Alopecia. J Pharm Res. 2011;4(4):1082-3.

17. Cornwell PA. A Review of Shampoo Surfactant Technology: Consumer Benefits, Raw Materials and Recent Developments. Int J Cosmet Sci. 2018;40:16-30.

18. Gavazzoni D, Reis MF. Hair Cosmetics: An Overview. Int J Trichology. 2015;7(1):2-15.

19. Ariani SRD, Susilowati E, VH ES, Setiyani. Activity Test of Guava (Psidium guajava L.) Leaf Methanol Extract As Contraception Antifertility to White Mice (Ratus norvegicus). Indo J Chem. 208AD;8(2):264-70.

20. Azadbakht M, Monadi T, Esmaeili Z, Chabra A, Tavakoli N. Formulation and Evaluation of Licorice Shampoo in Comparison with Commercial Shampoo. J Pharm Bioallied Sci. 2018;10(4):208-15.

21. Bakr RO, Amer RI, Fayed MA, Tamer RIM. A Completely Polyherbal Conditioning and Antioxidant Shampoo: A Phytochemical Study and Pharmaceutical Evaluation. J Pharm Bioallied Sci. 2019;11(2):105-15. 
22. Bisht LK, Jacob B, Chandy V. Evaluation Studies on Various Reputed Brands of Shampoo. Asian J Appl Sci Technol. 2017;1(6):23-5.

23. Upadhyay S, Ghosh AK, Singh V. Hair Growth Promotant Activity of Petroleum Ether Root Extract of Glycyrrhiza Glabra L (Fabaceae) in Female Rats. Trop J Pharm Res. 2012;11(5):753-8.

24. Emmawati T, Sidharta B, Puspita OE, Syafitri MH. Optimasi Formula dan Teknik Pembuatan Sampo Susu Sapi Segar Menggunakan Kombinasi Surfaktan dan Co-Surfaktan. Maj Kesehat FKUB. 2016;3(2):93-111.

25. R U, S D, P I. Preparation of Herbal Shampoo (HS) by Green Method and Their Characterization. IJRSSIS. 2017;5:254-8.

26. AlQuadeib BT, Eltahir EKD, Banafa RA, Al-Hadhairi LA. Pharmaceutical Evaluation of Diferent Shampoo Brands in Local Saudi Market. Saudi Pharm j. 2018;26(1):98-106.

27. Aghel N, Moghimipour E, Dana AR. Formulation of A Herbal Shampoo Using Total Saponins of Acanthophyllum squarrosum. Iran J Pharm Res. 2007;6(3):167-72.

28. Mesgarzadeh I, Akbarzadeh AR, Rahimi R. Surface-Active Properties of Solvent-Extracted Panax ginseng Saponin-Based Surfactants. J Surfact Deterg. 2017;20:609-14.

29. A. V, S. S, N. R. Formulation and Evaluation of Herbal Shampoo. Asian J Pharm Clin Res. 2018;11(4):121-4.

30. Kaushik R, Gupta D, Yadav R. Alopecia: Herbal Remedies. Int J Pharm Sci Res. 2011;2(7).

31. Roy RK, Thakur M, Dixit VK. Hair Growth Promoting Activity of Eclipta alba In Male Albino Rats. Arch Dermatol Res. 2008;300:357-64.

32. Jain PK, Das D, Jain P. Evaluating Hair Growth Activity of Herbal Hair Oil. Int J PharmTech Res. 2016;9(3):321-7.

33. Yadav N, Yadav R, Kharya MD. Development and Evaluation of Polyherbal Formulations for Hair Growth-Promoting Activity. IMPACT Int J Res Appl Nat Soc Sci. 2014;2(6):5-12.

34. Masyithoh PL, Utomo AW, Mahati E, Muniroh M. Perbandingan Efektivitas Ekstrak Gel Lidah Buaya (Aloe vera L.) Terhadap Pertumbuhan Sel Rambut. J Kedokt Diponegoro. 2019;8(4):1263-9.

35. Jusnita N, Syah RA. Formulasi dan Uji Stabilitas Fisik Sediaan Shampo dari Ekstrak Etanol Daun Pare (Momordica charantia Linn.). Indones Nat Res Pharm J. 2017;2(1):24-39.

36. Winarti $\mathrm{CH}$, Budiarti R. Formulasi dan Karakterisasi Shampo Anti Jamur dengan Penambahan Ekstrak Lengkuas Merah. j Pascapanen. 2007;4(2):97-104.

37. Rashati D, Christiningtyas EM. Pengaruh Variasi Konsentrasi HPMC Terhadap Mutu Fisik dan Stabilitas Sediaan Shampo Ekstrak Etanol Daun Katuk (Sauropus androgynus (L) Merr). J IIm Farm Akad Farm Jember. 2016;1(2):1-6.

38. Nguyen BCQ, Taira N, Maruta H, Tawata S. Artepillin C and Other Herbal PAK1-blockers: Effects on Hair Cell Proliferation and Related PAK1-dependent Biological Function in Cell Culture. Phyther Res. 2016;30:120-7.

39. Rashati D, Eryani MC. Evaluasi Sifat Fisik Sediaan Sampo Ekstrak Daun Katuk (Sauropus androgynus (L) Merr) dengan Berbagai Variasi Viscosity Agent. J Ris Kefarmasian Indones. 2019;1(1):56-63.

40. Herrwerth S, Wenk HH, Kortenmeier U, Grunung B, Ulrich-Brehm I, Quadir M. Hydroxypropyl Methylcellulose: A Unique Surface Active Polymer with Outstanding Versatility for Rinse-Off Applications. SOFW J. 2008;12(2-7).

41. Mercantili L, Davis F, Higson SPJ. Ultrasonic Initiation of the Alkaline Hydrolysis of Triglycerides (Saponification) Without Phase Catalysis. J Surfact Deterg. 2013;17(1):133-41. 
42. Surani F, Putriana NA. Evaluasi Berbagai Sediaan Shampo Herbal Antiketombe dan Antikutu: Review Artikel. Farmaka. 2017;15(2):218-32.

43. Kasim R, Barra ALS. Pengaruh Penambahan Lemak Kakao Terhadap Kestabilan, Efek Iritasi, dan Sifat Sensori Sampo Rambut. J Ind Has Perkeb. 2017;12(2):40-52.

44. Corcoran F, Akona K. The pH of Hair Shampos: A Topical High School Experiment. J Chem Educ. 1997;54.

45. Krunali T, Dhara P, MEshram DB, Mitesh P. Evaluation of Standards of Some Selected Shampoo Preparation. World J Pharm Pharm Sci. 2013;2(5):3622-30.

46. Sharquie KE, Al-Obaidi HK. Onion Juice (Allium cepa L.), A New Topical Treatment for Alopecia Areata. J Dermatol. 2002;29:343-6. 